UDC 821.161.1-32.09 Čehov A. P. https://doi.org/10.18485/ms_zmss.2021.100.23

\author{
Валерий Гречко \\ Университет Токио \\ VGretchko@hotmail.com \\ Valerij Gretchko \\ The University of Tokyo \\ VGretchko@hotmail.com
}

\title{
СЕМИОТИКА ПРОСТРАНСТВА В РАССКАЗЕ ЧЕХОВА «СКРИПКА РОТШИЛЬДА»: НЕСКОЛЬКО ИНТЕРТЕКСТУАЛЬНЫХ ПАРАЛЛЕЛЕЙ
}

\author{
THE SEMIOTICS OF SPACE IN CHEKHOV'S STORY \\ “ROTHSCHILD'S FIDDLE”: SOME INTERTEXTUAL PARALLELS
}

В статье рассматриваются интертекстуальные параллели рассказа А. П. Чехова «Скрипка Ротшильда», а также связанные с ними пространственные метафоры. В частности, обращается внимание на связь рассказа Чехова с евангельскими текстами и мотивами. История о воскрешении Лазаря рассматривается как интертекстуальный источник повествования о духовной трансформации героя чеховского рассказа Якова и анализируется сквозь призму оппозиции закрытого и открытого пространства, значимой для обоих текстов. Мотив денег, банковских процентов и упущенных возможностей сопоставляется с евангельской притчей о талантах. В качестве еще одного интертекстуального источника рассказа Чехова рассматривается новелла Э. Т. А. Гофмана «Советник Креспель» («Кремонская скрипка»). Метафорическое «одушевление» скрипки, характерное для немецких романтиков, получает у Гофмана амбивалентное выражение, при котором скрипка представляет собой как источник музыки, так и «мертвый кусок дерева», сковывающий ее свободу. Эта амбивалентность прослеживается и в рассказе Чехова, где скрипка, с одной стороны, становится метафорой души, а с другой - включается в ряд предметов, обозначающих замкнутые пространства. В статье показано, что представление о замкнутом пространстве, «футляре», является в творчестве Чехова сквозным мотивом, становящимся выражением экзистенциальной изоляции человека в мире.

Ключевые слова: А. П. Чехов, «Скрипка Ротшильда», интертекстуальность, пространственные метафоры, история о воскрешении Лазаря, притча о талантах, Э. Т. А. Гофман, «Советник Креспель».

The article examines some intertextual parallels of Chekhov's short story "Rothschild's Fiddle", as well as associated spatial metaphors. In particular, attention is drawn to the connection of Chekhov's story with Gospel texts and motifs. The story of the raising of Lazarus is considered as an intertextual source for the tale of the spiritual transformation of Yakov, the hero of Chekhov's story, and is analyzed through the prism of the opposition of closed and open space, significant for both texts. The motif of money, bank interest, and 
missed opportunities is compared to the Gospel parable of the talents. As a further intertextual source for Chekhov's story, E. T. A. Hoffmann's novella "Rat Krespel" ("Councilor Krespel") is considered. The metaphorical "humanization" of the violin, characteristic of the German Romantics, receives an ambivalent expression in Hoffmann, where the violin represents both the source of music and the "dead piece of wood" that restrains its freedom. This ambivalence can also be traced in Chekhov's story, where the violin, on the one hand, becomes a metaphor for the soul and on the other, is included in a series of objects denoting enclosed spaces. The article demonstrates that the idea of an enclosed space, a "container", is a recurring motif in Chekhov's work, expressing the existential isolation of man in the world.

Key words: A. P. Chekhov, "Rothschild's Fiddle”, intertextuality, spatial metaphors, the story of the raising of Lazarus, the parable of the talents, E. T. A. Hoffmann, "Councilor Krespel".

Увидевшая свет в 1894 году1 печальная история гробовщика Якова, лишь перед смертью осознавшего тщетность прожитой жизни, представляет собой один из самых пронзительных текстов русской литературы. Говоря о «Скрипке Ротшильда», Корней Чуковский замечает, что в этом рассказе заключена «квинтэссенция чеховского стиля» и характеризует его как «один из величайших шедевров, какие только знает мировое искусство» (Чуковский 2012: 308). Действительно, поставленные в рассказе важнейшие вопросы бытия, обличенные в форму нарочито незатейливого повествования, продолжают оставаться темой для размышления и источником создания новых произведений культуры вплоть до наших дней ${ }^{2}$.

Не обошли своим вниманием «Скрипку Ротшильда» и исследователи творчества Чехова. В многочисленных научных работах этот рассказ ставился в один ряд с теми произведениями писателя, в которых затрагиваются проблемы бессмысленности и абсурдности человеческого существования, подчеркивалась его социально-критическая направленность и изображение разлагающей власти денег ${ }^{3}$, а также выделялась еврейская проблематика ${ }^{4}$.

1 Рассказ «Скрипка Ротшильда» был первоначально опубликован в Русских ведомостях в феврале 1894 г., в том же году перепечатан в сборнике Повести и рассказы (Чехов 1894), а вскоре был включен в первое собрание сочинений писателя (Чехов 1899-1902).

2 В качестве наиболее значимых примеров можно выделить оперу Вениамина Флейшмана «Скрипка Ротшильда» (работа погибшего на войне Флейшмана была закончена Д. Шостаковичем в 1944 г. и после премьеры в 1968 г. запрещена за «сионизм»), одноименный рассказ И. Грековой, бард-оперу «Бронза, Марфа и чеснок» Сергея Никитина и Дмитрия Сухарева, а также театральную постановку рассказа, осуществленную режиссером К. Гинкасом. Известный писатель и сценарист Виктория Токарева отмечает впечатление, произведенное на нее этим рассказом, в качестве ключевого момента, побудившего ее начать литературную карьеру (Токарева 2015).

3 Естественно, что этот аспект произведения особо акцентировался в советской школе литературоведения, хотя он присутствовал уже и в дореволюционной «демократической критике». См. слова С. А. Андреевского о том, что в «Скрипке Ротшильда» читатель проникается «неимоверной жалостью к суровому терпению убогих, безвестных людей и к долгим сумеркам их упорной, тяжелой жизни» (Андреевский 1895). (Напомним, что Андреевский, юрист по первой профессии, отказался быть прокурором на процессе Веры Засулич).

4 Так, Ефим Эткинд считал, что «в центре "Скрипки Ротшильда" - еврейская тема», столкновение еврея и антисемита (Эткинд 1995: 132). См. также Rosenshield 1997, Litvak 2010. 
Все названные подходы, несомненно, затрагивают существенные стороны рассказа Чехова, если исходить из его текстуального уровня. Однако рассказ содержит мощный пласт интертекстуальных аллюзий и подтекстов, без прояснения которых глубинный чеховский замысел, очевидно, останется раскрыт не полностью. В данной статье мы попытаемся выйти за непосредственные рамки чеховского текста и проследить его интертекстуальные связи, которые еще в недостаточной мере привлекли внимание исследователей 5 . Ключом к этому нам послужит анализ пространственной структуры рассказа, открывающей ряд интересных и неожиданных интертекстуальных параллелей ${ }^{6}$.

\section{I}

В нашей более ранней работе мы уже кратко обращались к теме интертекстуального подтекста «Скрипки Ротшильда», отмечая, что одним из главных интертекстуальных источников этого рассказа являются евангельские притчи․ Сам рассказ также можно рассматривать как притчу, где сквозь повествование об унылой будничной реальности просвечивают глубокие философско-религиозные идеи ${ }^{8}$. Прежде всего, нужно обратить вни-

5 Елена Толстая в своей богатой тонкими наблюдениями книге о чеховском творчестве отмечает, что «многие произведения Чехова вообще еще никогда не были удовлетворительно прочитаны и поняты» (Толстая 2002: 9), обращая в этой связи внимание на «тотальную интертекстуальность Чехова» (там же: 339). Из немногочисленных работ, посвященных интертекстуальным параллелям «Скрипки Ротшильда», можно отметить статьи: Фортунатов 1976 и Рев 1990 (в которых рассматриваются связи с «Гробовщиком» Пушкина), Кубасов 2010 (связи с текстами Гоголя и Тургенева), Петрова 2011 (отсылки к творчеству Л. Толстого), а также пионерскую работу Jackson 1978, в которой в качестве интертекстуального источника чеховского рассказа рассматривается библейский псалом «На реках вавилонских».

6 Значение пространственных образов в художественных произведениях не ограничивается лишь изобразительными задачами. Посредством метафорического расширения они во многих случаях способны брать на себя концептообразующие функции, структурируя смысловое поле текста. См. замечание Ю. М. Лотмана: «Пространство в художественном произведении моделирует разные связи картины мира: временные, социальные, этические и т. п. [...] В художественной модели мира пространство подчас метафорически принимает на себя выражение совсем не пространственных отношений» (Лотман 1992: 414). Эти широкие возможности пространственных метафор коренятся в свойствах человеческой психики: как показали исследования в области когнитивной психологии и лингвистики, в основе большинства абстрактных понятий и представлений лежат вполне конкретные ментальные схемы, имеющие во многом пространственный характер (см. Lakoff 1990)

7 См. Гречко 2010. На важность христианских подтекстов в творчестве Чехова в целом указывают Сендерович 1994, De Sherbinin 1997, а Ранева-Иванова высказывает предположение, что использование Чеховым христианских мотивов может являться одним из «секретов» его прозы (Ранева-Иванова 1998: 484).

8 Комментируя свою театральную постановку «Скрипки Ротшильда», режиссер К. Гинкас замечает: «Чехов терпеть не мог ни притч, ни басен, потому что избегал нравоучений. По существу, Чехов впервые в своем творчестве почти напрямую сказал то, о чем всю жизнь писал. Впервые написал притчу, в которой позволил себе прямо сказать, что его беспокоит» (цит. по: Тимашева 2004: 19). 
мание на историю о воскрешении Лазаря, описанную в Евангелии от Иоанна (Ин. 11: 1-45). В Евангелии эта история приводится как одно из чудес Иисуса, доказательство его божественной сущности. Однако она может интерпретироваться и метафорически, как иносказание о духовном воскресении человека. При таком понимании смерть Лазаря истолковывается как духовная смерть, отход от идеалов христианства, а воскресение - как духовное возрождение, возвращение к людям через всеобщую христианскую любовь. Именно такое толкование легенда о Лазаре получает в романе Достоевского Преступление и наказание, где в роли Лазаря выступает Раскольников 9 .

Очевидно, что внутренняя трансформация главного героя, прослеживаемая в сюжетной линии чеховского рассказа, также укладывается в русло этой схемы. Путь от духовной смерти к духовному пробуждению, пройденный гробовщиком Яковом в конце жизни, на метафорическом уровне повторяет евангельскую историю о воскрешении Лазаря. Однако родство между двумя этими текстами можно проследить не только на метафорически-абстрактном, но и на вполне конкретном, структурно-текстуальном уровне. Хотя текст Чехова, в отличие от Преступления и наказания, не содержит прямых упоминаний о Лазаре, в рассказе присутствует большое количество имплицитных указаний на евангельскую легенду. Мы имеем в виду не только такие детали, как совпадение имен (жену Якова зовут Марфа - так же, как сестру Лазаря) или нумерологию (Лазарь лежит в гробу четыре дня, поэтому его также называют «Лазарь Четверодневный» духовная трансформация Якова занимает четыре дня, «четыре дня» прямо упомянуты в тексте рассказа) ${ }^{10}$. Гораздо важнее параллели с евангельской легендой, которые прослеживаются в общей структурной схеме рассказа.

Аналогично евангельской истории, рассказ построен на оппозиции жизнь - смерть ${ }^{11}$, причем в обоих текстах она раскрывается через пространственную метафору как противопоставление открытого и закрытого пространства. В Евангелии с почти навязчивой настойчивостью многократно подчеркнуто заключение умершего Лазаря в ряд оболочек, отграничивающих его от мира живых: Лазарь лежит в гробу, гроб находится в пещере, вход в пещеру придавлен камнем, а сам Лазарь спеленат саваном

9 Подробный разбор параллелей между легендой о воскрешении Лазаря и романом Достоевского см., например, в работах: Тихомиров 2005, Касаткина 2005, Тарасова 2020.

10 Символическое использование этого числа в качестве аллюзии на легенду о воскрешении Лазаря в Преступлении и наказании подробно рассмотрено в статье: Кофман 2021.

11 Отметим, однако, что у Чехова эта оппозиция приобретает парадоксальные черты: жизнь представлена как тюрьма, гроб, а смерть, наоборот, как пробуждение, спасение. Ю. Щеглов с полным основанием говорит в этой связи об «инверсии традиционного отношения к жизни и смерти» (Щеглов 2013: 467). Характерно, что, несмотря на схожее метафорическое понимание легенды о Лазаре в Преступлении и наказании, у Достоевского это обращение отсутствует - духовное пробуждение Раскольникова не связано с его смертью. В этом отношении рассказ Чехова заставляет скорее вспомнить «Смерть Ивана Ильича» Толстого. 
по рукам и ногам. В рассказе Чехова бездуховная жизнь Якова, которая подобна лежанию Лазаря в гробу, также изображается через целую цепь деталей, которые прямо или метафорически указывают на замкнутость пространства. Так, описывая провинциальный городок, в котором обитает Яков, Чехов считает нужным упомянуть лишь то, что там есть тюрьма и больница - традиционные символы закрытости и изоляции ${ }^{12}$. Яков живет в избе, где есть лишь одна комната, уставленная гробами, т. е. буквально почти в гробу. Эта «жизнь в гробу», метафорически равнозначная смерти, подчеркнута и такой характерной деталью, что Яков изготавливает гробы «на свой рост», снимая мерку с самого себя (а затем и со своей жены) нарушая тем самым строгое табу, запрещающее снимать мерку для гроба с живого человека ${ }^{13}$.

Прямые упоминания закрытых пространств дополняются многочисленными косвенными указаниями, метонимически маркирующими пространственную ограниченность. Здесь можно отметить нагнетаемое на протяжении всего рассказа ощущение духоты и застоявшегося воздуха, получающее свою реализацию через мотивы жары, неприятных запахов, жажды и их комбинации («было жарко, пахло чесноком до духоты» $(297)^{14}$, «лицо у него было багрово и мокро от пота» (298), «дыхание было горячее и тяжкое, ослабели ноги, тянуло к питью» (301) и т. д.).

В противоположность тесной, удушливой жизни, духовное пробуждение героя перед смертью связывается с выходом в открытое пространство. Его внутренняя трансформация сопровождается перемещением из тесной, уставленной гробами комнаты за город, к реке, с открывающейся до горизонта величественной панорамой природы. Летящие птицы - этот традиционный образ, указывающий на открытость и многомерность пространства - также многократно используется Чеховым в этом фрагменте. Момент духовного пробуждения Якова подкрепляется архетипическими символами: река как символ границы, перехода в иное состояние и яркий свет солнца, символизирующий духовное озарение («от воды шло такое сверканье, что было больно смотреть» (303)).

Пространственная оппозиция открытого/закрытого у Чехова дополнительно маркируется за счет цветовой символики. В рассказе явственно прослеживается противопоставление двух цветовых доминант — красного и белого, которые через синэстетические ассоциации связаны с закрытым

12 Об изоморфизме концептуальных моделей тюрьмы и больницы у Чехова см.: Suchanek 1990: 63.

13 См. Котович - Крук (2010: 466). Эта метафора получает прямое визуальное воплощение в сценической постановке «Скрипки Ротшильда» режиссера К. Гинкаса: в ней Яков действительно лежит на сцене в гробу (Цыбульская 2004).

14 Цитаты из рассказа «Скрипка Ротшильда» даются по изданию: Чехов 1974-1983, т. 8 (в скобках указывается лишь номер страницы). Другие произведения Чехова приводятся по тому же изданию с указанием тома и страницы. Так как в данном издании для художественных текстов и писем принята раздельная нумерация, в цитатах из писем перед номером тома ставится литера «П». 
и открытым пространством соответственно. Ощущение тесной, удушливой жизни раскрывается через темно-красный, багровый цвет - цвет застоявшейся крови. Рассказ буквально насыщен подобными примерами: многократно упоминается багровое лицо Якова («у него прежде всего потело и багровело лицо» (297), «Яков тоже вспылил и побагровел весь» (300)), разговор в больнице также концентрируется вокруг застоявшейся крови («банки», «пьявки», «кровь гнать» (там же)), кроваво-красный колорит нагнетается Чеховым и в, казалось бы, случайных деталях (встреченная на реке «полная краснощекая дама», ловящие на мясо раков мальчишки (303) и т. д.). В этом ключе можно истолковать и прозвище героя рассказа Бронза, металлический сплав золотисто-красного цвета ${ }^{15}$. С другой стороны, открытое пространство и связанное со смертью духовное возрождение героя поддерживаются через метафору белого цвета, см. проносящиеся перед ним в момент просветления воспоминания об умершем ребенке с белокурыми волосами, срубленном березовом лесе, стадах белых гусей (303) и т. д.

\section{II}

Еще одна важная линия, которая проходит через весь рассказ - это мотивы денег и банка. Ассоциацию с миром банков Чехов задает уже в заглавии рассказа (не без горькой иронии, ибо за именем всемогущего банкира скрывается бедный музыкант из провинциального оркестра). Мысли гробовщика Якова постоянно вращаются вокруг денег, причем с первых строк рассказа размышления о них проводятся в ирреально-условной модальности, где ключевым становится союз «если бы». Яков постоянно думает о нереализованных возможностях богатства, «убытках», размышляет о том, сколько процентов могли бы принести деньги, если бы он их положил в банк.

Мотив денег и процентов подводит нас к еще двум евангельским сюжетам, с которыми рассказ Чехова обнаруживает неожиданные, но ясно прослеживаемые параллели. Прежде всего, речь идет о хорошо известной притче о талантах (Мф. 25: 14-30), в которой некий господин, уходя в длительное путешествие, дает своим рабам на хранение несколько талантов серебра. Возвратившись, он одобряет тех, кто занял деньги торговцам и получил на них проценты. Того же, кто зарыл свой талант в землю и не преумножил оставленный ему капитал, он бранит: «Подобаше убо тебе вдати

15 В тексте рассказа Чехов демонстративно подчеркивает случайность прозвища Якова («уличное прозвище у него было почему-то - Бронза» (297, курсив мой - В. Г.)). Именно это специальное акцентирование «случайности» заставляет предположить, что выбор Чехова был тщательно продуман. Заметим, что имя другого персонажа, Ротшильда, также продолжает символический ряд «красного» и задает парность двух главных героев рассказа (фамилия Ротшильд происходит от немецких слов «rot» (красный) и «Schild» (щит, вывеска). 
сребро мое торжником: и пришед аз взял бых свое с лихвою», т. е. с процентами, отбирает у него последний талант и изгоняет во «тьму кромешную».

Несмотря на то, что христианская церковь, в принципе, осуждает ростовщичество как небогоугодное дело (в Средневековье эту «грязную работу» оставляли «неверным» евреям) ${ }^{16}$, в данном евангельском тексте взимание процентов на вложенные деньги расценивается как благо. Причина этого кажущегося противоречия, конечно же, в том, что этот текст - притча, и содержащееся в нем послание не следует воспринимать буквально. В толкованиях Евангелия говорится, что в этой притче речь идет об Иисусе, оставившем людям свои заповеди, которые надлежит распространить и преумножить ${ }^{17}$.

Представляется, что Чехов в своем рассказе отсылает читателя к этому евангельскому тексту. Здесь мы имеем в виду не только прямое упоминание о таланте, имеющемся у Якова, которое содержится в тексте рассказа («Если бы я не уважал вас за талант, то вы бы давно полетели у меня в окошке» (298))) ${ }^{18}$. Рассуждения Якова о неиспользованных возможностях и своей «убыточной жизни» приобретают явное сходство со смыслом притчи в конце рассказа, где они получают обобщенное религиозно-моральное звучание, созвучное евангельским заповедям: «И почему человек не может жить так, чтобы не было этих потерь и убытков? [...] Зачем вообще люди мешают жить друг другу? Ведь от этого какие убытки! Какие страшные убытки! Если бы не было ненависти и злобы, люди имели бы друг от друга громадную пользу» (304). Таким образом, мысли Якова о «пользе», банковских процентах переосмысливаются в свете христианских идеалов всеобщей любви, а у Иисуса обнаруживается сходство с банкиром, только он призывает вкладывать в свой «банк» не деньги, а любовь к ближнему, и лишь такие вклады принесут людям настоящие «проценты». Характерно, что эта мысль в Евангелии также иллюстрируется через пространственную метафору — талант не должен быть заточен под землей.

В Евангелии имеется и еще одна история, в которой удивительным образом сходятся мотивы Лазаря, денег и закрытого пространства, определяющие для чеховского рассказа. Речь идет о другом евангельском Лазаре,

16 Негативное отношение к взиманию процентов является, по-видимому, универсальным и прослеживается в самых разных культурах, а в европейской традиции представлено уже у Аристотеля, который считал этот род обогащения «противным природе» (Аристотель 1983: 395). См. длинный ряд вызывающих отвращение фигур «процентщиков» в мировой литературе, опять же возвращающий нас к Преступлению и наказанию.

17 Св. Иоанн Златоуст, толкование на Мф. 25: «Серебром он называет драгоценное слово (Божие), а торжниками — вас, принимающих (от нас) это слово». <https://ekzeget.ru/ bible/evangelie-ot-matfea/glava-25/tolkovatel-ioann-zlatoust-svatitel/>.

18 Чехов обыгрывает здесь два значение слова «талант» - «старинная мера веса, денежная единица» и «дарование, способность». О том, насколько широко притча о талантах была представлена в сознании говорящих на русском языке, свидетельствует тот факт, что само значение слова «талант» как «дарование» развилось из евангельской притчи (Фасмер 1987, т. 4: 415), а выражение «зарыть свой талант в землю» стало устойчивым фразеологическим выражением, указывающим на нереализованные возможности. 
на этот раз из притчи о Лазаре и богаче (Лк. 16: 19-31). Социальная пропасть между двумя персонажами этой притчи также ясно маркирована в евангельском тексте за счет пространственного разграничения. Нищий Лазарь, при жизни отделенный от богача непреодолимым порогом («лежал у ворот его»), вознесен после смерти на небо, богач же заточен в подземном пекле, из которого нет выхода («между нами и вами утверждена великая пропасть, так что хотящие перейти отсюда к вам не могут, также и оттуда к нам не переходят»). Кроме чрезвычайно важной для Чехова темы ограниченного пространства и непреодолимости границы, о которой речь еще пойдет ниже, а также мотива жара и жажды (Лк. 16: 24), также получившего отражение в рассказе, имеется и еще один момент, на который мы хотели бы обратить внимание.

Рискнем высказать предположение, что все три рассмотренные нами евангельские истории оказали влияние на выбор имен главных персонажей рассказа. Как отмечает Еремин, «в поздних произведениях Чехова, по всей вероятности, нет случайных имен» (Еремин 1991: 96). С этим утверждением можно согласиться, однако в поисках именных прототипов здесь нужно делать поправку на чеховский стиль, неотъемлемыми составляющими которого являются ирония и парадокс. Во многих случаях прояснение фигур и образов, стоящих за именами его героев, является несравненно более трудной задачей, чем, например, прямолинейные толкования «говорящих» имен типа Молчалина или Раскольникова.

При рассмотрении имен главных персонажей «Скрипки Ротшильда» заслуживает внимания следующий факт. В конце XIX века в России был широко известен банкир, получивший прозвище «московский Ротшильд». Звали его Лазарь Поляков. Финансовый магнат, меценат, деятель еврейской культуры - колоритная фигура, несомненно, заслуживающая отдельного всестороннего исследования ${ }^{19}$. В данном же контексте нас прежде всего интересует его возможная связь с чеховским рассказом. Учитывая активное присутствие Лазаря Полякова в общественной и культурной жизни тогдашней Москвы, не будет слишком смелым предположить, что Чехову было хорошо знакомо это имя. Приходилось ему и лично встречаться с семьей Поляковых ${ }^{20}$. Между Чеховым и Поляковыми прослеживаются и более глубокие биографические связи - в 1870-е годы центр их финансовой деятельности приходится на Таганрог ${ }^{21}$. К этому остается лишь добавить, что

19 О масштабе деятельности Лазаря Полякова красноречиво свидетельствует уже краткий список его заслуг и регалий: председатель еврейской общины Москвы и российский дворянин, спонсор строительства Московской хоральной синагоги и Музея изящных искусств имени Александра III (ныне Государственный музей изобразительных искусств имени А. С. Пушкина), персидский консул в Москве, тайный советник и - не в последнюю очередь - предполагаемый отец знаменитой балерины Анны Павловой (Ананьич 1991; Петров 2010).

20 См. замечание в письме Чехова А. С. Суворину из Биаррица: «Здесь Поляков с семейством. Гевалт!» (П 7: 49).

21 В конце 1860-х годов Поляковы были причислены к таганрогским купцам первой гильдии и получили звание потомственных почетных граждан. 
у Лазаря Полякова был старший брат, также крупный банкир, владелец Азовско-Донецкого банка в Таганроге, и звали его Яков.

Ассоциативная связь Ротшильд - Поляков, закрепленная в прозвище «московский Ротшильд», прослеживается уже в ранних чеховских текстах, где имена этих банкиров соседствуют друг с другом, употребляясь через запятую 22 . Можно предположить, что оксюморонное сочетание «Лазарь московский Ротшильд» в силу своего парадоксального соединения символов крайнего богатства и крайней бедности ${ }^{23}$ привлекло внимание писателя и послужило одним из внешних триггеров, который, преломившись сквозь призму евангельских сюжетов, привел к развитию замысла рассказа ${ }^{24}$. Имена «московского Ротшильда» Лазаря и его брата Якова становятся именами героев рассказа, в котором темы смерти, духовного воскресения, христианской любви и банковских процентов оказываются связаны таким же парадоксальным образом.

\section{III}

В заключение мы коснемся еще одного момента, который, как нам представляется, лежит в основе глубинной концепции этого рассказа и является реализацией одной из центральных тем чеховского творчества в целом. Обратимся к мотиву скрипки, значение которого сразу же подчеркивается тем, что название этого инструмента вынесено в заглавие рассказа. Представляется, что скрипка и связанные с ней метафорические смыслы являются ключом к пониманию замысла Чехова, и они также включают с себя пространственную символику.

Скрипка - это единственное человеческое, что осталось у Якова, и именно скрипка открывает ему путь к спасению. Вспомним, что Яков берет скрипку, когда ему становится плохо. Во время бессонных ночей «он клал рядом с собой на постели скрипку и, когда всякая чепуха лезла в голову, трогал струны, скрипка в темноте издавала звук, и ему становилось легче» (298). Логично задать вопрос - а откуда у Якова такая хорошая скрипка и как он научился на ней играть? С точки зрения жизненных реалий того времени бедный гробовщик, владеющий великолепной скрипкой и хорошо играющий на ней, представляется фигурой мало правдоподобной. Чехов никак не объясняет это несоответствие, скрипка Якова присут-

22 Например, юмористический совет из рассказа «Домашние средства»: «Возьми Ротшильда, барона Гинцбурга и Полякова, посади их играть с тобой в стуколку и валяй в крупную. Чем крупнее ставка, тем лучше. Если ты проиграл, то не отдавай, так как у твоих партнеров и без того много денег, если же выиграл, то твое счастье» (4: 185).

23 См. вошедшие в язык под воздействием евангельской притчи выражения, указывающие на бедность и немощность - «петь Лазаря», «лазарет» и др.

24 См. замечание Т. Л. Щепкиной-Куперник о внимании Чехова к необычным именам и их сочетаниям: «О том, что пишет, говорил мало. Так разве скупо поделится названием того рассказа, который пишет в это время, и содержанием в двух словах [...] Или вынет свою записную книжку и прочтет какое-нибудь поразившее его название станции или имя вроде "Розалия Аромат”» (Щепкина-Куперник 1986: 242). 
ствует в рассказе просто как данность. Это наводит нас на мысль о символическом характере данного инструмента.

Связь музыки с эмоциональной и духовной сферой является широко укорененным представлением, понимаемым уже на интуитивном уровне. Некоторые музыкальные инструменты (в особенности деревянные духовые, такие как свирель или флейта) издавна используются в разных культурах как архетипические образы человеческой души (ср., например, легенду о Пане и Сиринге $)^{25}$. С развитием идей европейского романтизма, особенно немецкого романтизма конца XVIII - начала XIX века (которое совпало с развитием канона классической музыки и присущих ей форм инструментовки, а также концертного и домашнего музицирования), эту роль метафорического выразителя человеческого духа наряду с флейтой заняла скрипка. Придание скрипке человеческих качеств, ее «одушевление» прослеживается уже в названии частей этого инструмента, один из ключевых элементов которого получил название душка (итал. anima). Ассоциации скрипки с душой и ее особой роли в поэтике романтизма, очевидно, способствовал специфический характер звукоизвлечения, который, с одной стороны, основан на индивидуальной мелодической линии, а с другой обладает широким диапазоном динамических возможностей. В немецком романтизме за скрипкой закрепляется почти мистический ореол, см., например, характеристику скрипки, данную Э. Т. А. Гофманом: «этот инструмент, заключающий в себе, при его видимой неприхотливой простоте, неимоверное богатство звука, есть чудесная тайна, которая открывается лишь немногим, особо избранным для того людям» (Гофман 1999: 222) 26.

Понимание скрипки как символа духа или души, особенно в свете отмеченного выше евангельского контекста чеховского рассказа, дает возможность истолковать примиряющую роль этого инструмента в конфликте Якова и Ротшильда, где антагонизм между евреем и антисемитом оказывается несущественным перед лицом общечеловеческого единства. Подобно неизвестно почему имеющейся у Якова скрипке, душа есть у каждого человека от рождения, просто потому, что он человек, и это объединяет всех людей и делает их братьями и сестрами (см. повторяющиеся в рассказе сцены совместного плача, доносящие идею всеобщей сим-патии, со-чувствия) ${ }^{27}$.

25 Здесь мы оставляем в стороне очевидно связанную с этим образом паскалевскую метафору «мыслящего тростника» и восходящую к ней богатую литературную традицию, в русской литературе прослеживаемую от Лермонтова и Тютчева до Ахматовой и Вознесенского.

26 Ряд высказываний романтиков, видящих в скрипке мистическое продолжение человеческой души, можно продолжить. См. слова Гейне: «Скрипка - инструмент, почти человечески капризный и находящийся, так сказать, в симпатическом соответствии с расположением духа скрипача» (Гейне 1958: 207) или его же характерное замечание о выступлении скрипача Шарля Берио (мужа легендарной певицы Мелибран): «порой я не могу отделаться от мысли, что в скрипке его заключена душа его покойной жены» (там же: 134).

27 Важный для рассказа мотив совместного плача еще раз возвращает нас к легенде о воскрешении Лазаря. Это единственное место в Евангелии, где Иисус плачет вместе с людьми, что толкуется как указание на его человеческую природу (в качестве еще одной 
Отмеченная выше аллюзия на Иисуса как банкира, заключенная в притче о талантах, материализуется в рассказе Чехова в фигуре Ротшильда, причудливым образом соединяющей в себе ассоциативные поля, ведущие, с одной стороны, к владельцу могущественного банкирского дома, a с другой - к кругу идей и образов, сближающих ее с представлением об Иисусе (наряду с очевидным иудейским мотивом, упомянем здесь, среди прочего, настойчиво подчеркиваемую писателем «детскость» чеховского Ротшильда (Еремин 1991: 113), а также тот факт, что в оркестре Ротшильд играет печальные мелодии на флейте) ${ }^{28}$. Принимая во внимание эти ассоциативные связи между фигурами Ротшильда и Иисуса, можно предположить, что выражение «Скрипка Ротшильда» содержит в себе ключевую для рассказа метафору данной людям божественной души, духа Божия, и не случайно именно оно выделено в качестве его названия. Обратим внимание на то, что рассказ назван «Скрипка Ротшильда», а не «Скрипка Якова», что было бы более логичным, исходя из сюжета. Параллель Ротшильд Иисус, возникающая в рассказе, делает выбор Чехова хорошо объяснимым.

Но почему метафорой души у Чехова, писателя, как принято считать, далекого от поэтики романтизма, становится именно скрипка? Представляется, что в «Скрипке Ротшильда» тема скрипки имеет под собой вполне конкретный интертекстуальный источник.

Мы не случайно упомянули выше имя Э. Т. А. Гофмана. В анализе чеховского текста отсылка к его творчеству является довольно неожиданной, ведь о связях Чехова и этого писателя-романтика чеховедению известно очень мало. Так, в 30-томном собрании сочинений Чехова с обширными примечаниями и комментариями имя Гофмана упоминается лишь один раз, и то по косвенному поводу 29 . Однако отдельные указания на связь между этими писателями все же имеются. В частности, обращается внимание на то, что в рассказе «Черный монах» используются мотивы из романа Гофмана Эликсир сатаны (Кочетов 1996: 42). Представляется, что и в рассказе «Скрипка Ротшильда», который был написан непосредственно после «Черного монаха» ${ }^{30}$, можно проследить прямое влияние гофмановских

интертекстуальной параллели этого мотива Р. Джексон называет псалом «На реках вавилонских», см. Jackson 1978). М. Вайскопф указывает и на возможный реальный источник, повлиявший на Чехова - сообщение в московской прессе об изобретенном «одним житомирским евреем» музыкальном инструменте, на котором нельзя играть «ни одной пьесы веселого характера» и слушая который все плачут навзрыд (Вайскопф 2005: 235).

28 В толкованиях Евангелия Иисус нередко уподобляется играющему на свирели музыканту: «Господь играл нам на свирели в драгоценных обетованиях Евангелия и пел печальные песни в грозных предупреждениях Закона» (https://pravoslavie.ru/3392.html). Подобные сравнения восходят к евангельской фразе: «Мы играли вам на свирели, а вы не плясали, мы пели вам печальные песни, а вы не рыдали» (Мф. 11: 17).

29 В связи с неосуществленным планом Чехова написать пьесу об истории венецианского дожа Марино Фальери, которая была использована, в частности, в рассказе Гофмана «Дож и догаресса» (17: 251).

30 Работа по написанию «Черного монаха» велась летом — осенью 1893 г. (см. 8: 488), а время написания «Скрипки Ротшильда» определяется как декабрь 1893 - январь 1994 г. (8: 502-503). 
произведений. Именно здесь и возникает тема скрипки. Речь идет о новелле Гофмана «Rat Krespel» (1818), которая была впоследствии включена в цикл Серапионовы братья. В современном переводе на русский язык немецкое заглавие «Rat Krespel» передается как «Советник Креспель», однако в XIX начале XX века использовалось другое название - «Кремонская скрипка» ${ }^{31}$. Эта новелла Гофмана обнаруживает целый ряд интересных параллелей со «Скрипкой Ротшильда» 32 , здесь же мы ограничимся лишь указанием на мотив скрипки, являющийся центральным для обоих произведений.

Как и у Чехова, в гофмановском рассказе скрипка выступает символом души, с ней идентифицируются лучшие и наиболее глубинные стороны человеческой сущности героев. Сопоставление с рассказом Гофмана позволяет осознать очень существенный аспект чеховского творчества, который в «Скрипке Ротшильда» выражен лишь латентно. У Гофмана ярко проводится тема двоякой природы скрипки. С одной стороны, это источник музыки, метафора высшего проявления духовности. С другой же стороны скрипка - это «мертвый кусок дерева» (Гофман 1998: 36), скрывающий, сковывающий в себе музыку, не дающий ей вырваться на свободу. У героя новеллы Гофмана странное увлечение - он разбирает скрипки на части, стремясь найти внутри деревянной оболочки сущность музыки. Музыка спрятана внутри инструмента, и когда он на нем играет, у него возникает странное чувство, будто он «всего лишь магнитезер, сумевший пробудить сомнамбулу, которая теперь по собственному побуждению облекает в слова свои самые сокровенные мысли» (там же). Гофман продолжает метафору духовной сущности, скованной оболочкой, и выводит ее на экзистенциальный уровень. Замкнутость музыки внутри пустого корпуса скрипки оказывается аналогичной замкнутости человеческой души, заключенной в оболочку земного существования. Центральным в этом отношении являются слова героя, говорящего про «томящийся в нас дух, зажатый в тиски ничтожной земной суеты» (там же: 41).

Возвращаясь к рассказу Чехова, мы видим, что проблематика открытого и закрытого пространства, о которой говорилось выше, после прочтения новеллы Гофмана получает дополнительное измерение. Скрипка становится амбивалентным символом, являясь, с одной стороны, метафорой души, но одновременно включаясь в ряд предметов, обозначающих замкнутые пространства. В этом смысле скрипка становится эквивалентной гробу 33 .

31 В частности, под таким названием новелла Гофмана была напечатана в двухтомном издании М. М. Ледерле, вышедшем как раз в период написания чеховского рассказа (см: Гофман 1893).

32 Например, мотив дома без окон и дверей (дом-гроб) или мотив дефенестрации (выбрасывания из окна).

33 На их фактическое (и то и другое - полые деревянные предметы) и звуковое сходство («сКРиПка - ГРоБ») обращается внимание в работе Шмид (1998: 229). Добавим, что это звуковое сходство еще более очевидно в написании «гроп», которое Чехов использует 
Рассматривая творчество Чехова в более широкой перспективе, нетрудно заметить, что заключение в замкнутое пространство является сквозным, почти навязчивым представлением писателя. Во многих рассказах эта тема выражена эксплицитно или даже отражена в названиях («Роман с контрабасом» ${ }^{34}$, «Человек в футляре», «Палата №6» и т. д.). Традиционный для Чехова топос провинциального города также можно рассматривать в этом контексте. Вариацию той же темы представляют собой рассказы, тематизирующие заключение и постепенное удушение духовных потенций героя в тесном пространстве своих привычек и повседневности («Крыжовник», «Ионыч» и др.). Нередко Чехов сам дает указания, ведущие читателя от буквального к метафорическому пониманию мотива закрытого пространства. Вспомним слова героя рассказа «Человек в футляре»: «А разве то, что мы живем в городе в духоте, в тесноте, пишем ненужные бумаги, играем в винт — разве это не футляр?» (10: 53).

Исследователи уже обращали внимание на эту «футлярность» в произведениях Чехова. В советской критике она прежде всего связывалась с социально-критическими проблемами, характерными для дореволюционной России ${ }^{35}$. В других работах «футлярность» понимается скорее в более широком психологическом ключе, как отчуждение, возникающее между индивидуумом и средой его обитания. Карл Крэмер, например, определяет ее как «физическую, психическую, нравственную и духовную изоляцию человека от мира» (Kramer 1970: 62). Однако рассмотрение интертекстуальных образов и представлений, связывающих «Скрипку Ротшильда» с творчеством Гофмана, открывает возможность и для более широкого понимания столь важного для Чехова мотива «футлярности». Речь идет об изоляции экзистенциальной, заключении человеческого духа в бренную оболочку тела, его томлении в плену мироздания, не имеющего ни причины, ни цели. Этот мотив отчетливо звучит в словах доктора Рагина из «Палаты №6»: «Жизнь есть досадная ловушка. Когда мыслящий человек достигает возмужалости и приходит в зрелое состояние, то он невольно чувствует себя как бы в ловушке, из которой нет выхода. В самом деле, против его воли вызван он какими-то случайностями из небытия к жизни... Зачем? Хочет он узнать смысл и цель своего существования, ему не говорят или

в первоначальном наброске сюжета своего рассказа («Гроп для Ольги», 8: 502). См. замечание В. А. Поссе о том влиянии, которое оказывали чувственно воспринимаемые образы на творческий процесс Чехова: «Чехов говорил мне, что страдает от наплыва сюжетов, порождаемых впечатлениями зрительными и слуховыми» (Поссе 1986: 459).

34 Заметим, что необычный мотив помещения человека в футляр от контрабаса, возможно, также отсылает нас к Гофману, см. эпизод из его сказки «Крошка Цахес, по прозванию Циннобер», в котором «итальянский скрипач Сбьокка грозил засунуть господина Циннобера в контрабас» (Гофман 1996: 206).

35 Так, 3. Паперный распространяет этот чеховский мотив на «всю российскую действительность» (Паперный 1954: 129-130) (что, в свою очередь, восходит к известным словам Н. Лескова: «В “Палате № 6” в миниатюре изображены общие наши порядки и характеры. Всюду — палата № 6. Это — Россия», см. Лесков 1947: 316). 
же говорят нелепости; он стучится - ему не открывают; к нему приходит смерть - тоже против его воли» $(8: 89)^{36}$.

Таким образом, в «Скрипке Ротшильда» реализуется один из центральных тематических инвариантов творчества Чехова. Своеобразие этого рассказа проявляется в том, что пространственная метафора тесноты, заключения в оболочку одновременно получает свое воплощение через образы двух конкретных предметов, каждый из которых восходит к своим источникам. Гроб и воскресение, ведущие к евангельской легенде о Лазаре, и амбивалентный образ скрипки, отсылающий нас к Гофману, сходятся вместе, создавая уникальное единство на метафорическом, концептуальном и даже фонетическом уровне.

\section{ЛИТЕРАТУРА}

Ананьич Борис. Банкирские дома в России 1860-1914 гг. Очерки истории частного предпринимательства. Москва: Наука, 1991.

Аристотель. «Политика». Пер. С. А. Жебелева. Аристотель. Сочинения: $B 4$ m. Т. 4. Москва: Мысль, 1983: 376-644.

Вайскопф Михаил. «Извлечения. Юбилейное приношение автору “Записей и выписок”. Голос Ротшильда». Новое литературное обозрение 73 (2005): 235.

Гейне Генрих. «Лютеция». Собрание сочинений: В $10 \mathrm{~m}$. Т. 8. Москва: Государственное издательство художественной литературы, 1958.

Гофман Э. Т. А. Рассказы. Т. 1-2. Пер. С. М. Брильянта и 3. Н. Журавской. Санкт-Петербург: М. М. Ледерле, 1893.

Гофман Э. Т. А. «Крошка Цахес, по прозванию Циннобер». Собрание сочинений: 86 m. Т. 3. Москва: Художественная литература, 1996: 171-267.

Гофман Э. Т. А. «Серапионовы братья. [Советник Креспель]». Собрание сочинений: $B 6$ m. Т. 4, кн. 1. Москва: Художественная литература, 1998: 29-54.

Гофман Э. Т. А. «Серапионовы братья. [Барон фон Б.]». Собрание сочинений: $В 6$ m. Т. 4, кн. 2. Москва: Художественная литература, 1999: 220-230.

Гречко Валерий. «К проблеме религиозного субтекста в произведениях Чехова». Реникса, Токио, 2 (2010): 148-160.

Еремин П. «“Скрипка Ротшильда” А. П. Чехова - связь с традициями русской классики». Вопросы литературы 4 (1991): 93-123.

Касаткина Татьяна. «Воскрешение Лазаря: опыт экзегетического прочтения романа Ф. М. Достоевского “Преступление и наказание”». Касаткина Татьяна (ред.) Достоевский: дополнения к комментарию. Москва: Наука, 2005: 203-235.

Котович Оксана, Крук Янка. Золотые правила народной культуры. Мінск: Адукацыя и выхаванне, 2010.

Кофман Андрей. «Следуя путями Бахтина...» Bakhtiniana, São Paulo, 16 (2) (2021): 124-141.

Кочетов Дмитрий. «Чехов и Гофман: поэтика рубежных эпох». Катаев Дмитрий и др. (ред.) Чехов и Германия. Москва: МГУ, 1996: 37-42.

Кубасов Александр. «Семантика нарративной структуры рассказа А. П. Чехова “Скрипка Ротшильда"». Филологический класс 2 (24) (2010): 67-72.

Лесков Андрей. «Из записей и памяти». А. П. Чехов в воспоминаниях современников. Москва: Государственное издательство художественной литературы, 1947: 312-322.

Лотман Юрий. «Проблема художественного пространства в прозе Гоголя». Лотман Юрий. Избранные статьи: В 3 m. Т. 1. Таллинн: Александра, 1992: 413-447.

36 Напомним, что в «Палате № 6», написанной в 1892 г., уже появляется образ скрипки как человеческой души, ставший центральным в «Скрипке Ротшильда», см. размышления доктора Рагина: «Видеть свое бессмертие в обмене веществ так же странно, как пророчить блестящую будущность футляру после того, как разбилась и стала негодною дорогая скрипка» (8: 91). 
Паперный Зиновий. А. П. Чехов. Очерк творчества. Москва: Государственное издательство художественной литературы, 1954.

Петров Юрий. «Лазарь Поляков: “московский Ротшильд”». Ананьич Борис и др. (ред.) Частное предпринимательство в дореволючионной России: этноконфессиональная структура и региональное развитие, ХІХ - начало ХХ в. Москва: РОССПЭН, 2010: 411-436.

Петрова Светлана. «Скрипка Ротшильда» в творческом диалоге А. П. Чехова и Л. Н. Толстого. Пушкинские чтения. Санкт-Петербург, 2011: 302-307.

Поссе Владимир. «Воспоминания о Чехове». А. П. Чехов в воспоминаниях современников. Москва: Художественная литература, 1986: 457-464.

Ранева-Иванова М. «К проблеме теории и метода изучения христианского мотива в прозе А. П. Чехова (о значении пасхального мотива в рассказе “Казак”)». Евангельский текст в русской литературе XVIII-XX веков. Вып. 2. Петрозаводск: Изд-во Петрозаводского университета, 1998: 484-492.

Рев Мария. «Видоизменение одной литературной традиции (Пушкин и Чехов)». Studia Slavica Academiae Scientiarum Hungaricae 36 (1-4) (1990): 325-334.

Сендерович Савелий. Чехов - с глазу на глаз. История одной одержимости А. П. Чехова. Санкт-Петербург: Дмитрий Буланин, 1994.

Тарасова Наталья. «“Воскресение” и “воскрешение” в романе Ф. М. Достоевского “Преступление и наказание”». Проблемы исторической поэтики 18 (2) (2020): 190-216.

Тимашева Марина. «Раз ты человек, то ты есть испытатель боли». Петербургский театральный журнал 3 (37) (2004): 14-19.

Тихомиров Борис. «Лазарь! гряди вон». Роман Ф. М. Достоевского «Преступление и наказание» в современном прочтении: книга-комментарий. Санкт-Петербург: Серебряный век, 2005.

Токарева Виктория. «Обо всем понемножку». Токарева Виктория. Муля, кого ты привез? Рассказы. Санкт-Петербург: Азбука-Аттикус, 2015.

Толстая Елена. Поэтика раздражения: Чехов в конще 1880-х - начале 1890-х годов. Изд. 2-е. Москва: РГГУ, 2002.

Фасмер Макс. Этимологический словарь русского языка: $B 4$ m. Москва: Прогресс, 1987.

Фортунатов Николай. «“Гробовщик” Пушкина и “Скрипка Ротшильда” Чехова». Болдинские чтения. Горький: Волго-Вятское книжное изд-во, 1976: 93-103.

Цыбульская Алла. «“Скрипка Ротшильда” на американской сцене». Чайка 3 (14) (2004). $<$ https://www.chayka.org/node/352>.

Чехов Антон. Повести и рассказы. Москва: Типогр. т-ва И. Д. Сытина, 1894.

Чехов Антон. Сочинения: В 10 т. Санкт-Петербург: Изд. А. Ф. Маркса, 1899-1902.

Чехов Антон. Полное собрание сочинений и писем: В 30 т. Москва: Наука, 1974-1983.

Чуковский Корней. «О Чехове». Чуковский Корней. Собрание сочинений: В 15 т. Т. 4. Москва: Агенство ФТМ, 2012: 195-378.

Шмид Вольф. Проза как поэзия: Пушкин, Достоевский, Чехов, авангард. Санкт-Петербург: Инапресс, 1998.

Щеглов Юрий. «Две вариации на тему смерти и возрождения: “Дама с собачкой” и “Скрипка Ротшильда” Чехова». Щеглов Юрий. Избранныле труды. Москва: РГГУ, 2013: 462 482.

Щепкина-Куперник Татьяна. «О Чехове». А. П. Чехов в воспоминаниях современников. Москва: Художественная литература, 1986: 227-260.

Эткинд Ефим. «Иванов и Ротшильд». Вопросы литературы 4 (1995): 131-152.

De Sherbinin Julie. Chekhov and Russian Religious Culture: The Poetics of the Marian Paradigm. Evanston: Northwestern University Press, 1997.

Jackson Robert Louis. "If I Forget Thee, O Jerusalem' (An Essay on Chekhov's 'Rothschild's Fiddle". Slavica Hierosolymitana 3 (1978): 55-67.

Kramer Karl. The Chameleon and the Dream: The Image of Reality in Čexov's Stories. The Hague: Mouton, 1970.

Lakoff George. "The Invariance Hypothesis: Is Abstract Reason Based on Image-Schemas?" Cognitive Linguistics 1 (1) (1990): 39-74.

Livak Leonid. The Jewish Persona in the European Imagination: A Case of Russian Literature. Stanford: Stanford University Press, 2010. 
Rosenshield Gary. "Dostoevskii's 'The Funeral of the Universal Man' and 'An Isolated Case' and Chekhov's 'Rothschild's Fiddle': The Jewish Question”. Russian Review 56 (4) (1997): 487-504.

Suchanek Lucjan. «Пространство здоровья и пространство болезни (Палата №6, 1892)». Kluge Rolf-Dieter (Hrsg.) Anton P. Čechov. Werk und Wirkung. Teil 1. Wiesbaden: Otto Harrassowitz, 1990: 58-67.

\section{LITERATURE}

Anan'ich Boris. Bankirskie doma v Rossii 1860-1914 gg. Ocherki istorii chastnogo predprinimatel'stva. Moskva: Nauka, 1991.

Aristotel'. «Politika». Per. S. A. Zhebeleva. Aristotel'. Sochineniya: V 4 t. T. 4. Moskva: Mysl', 1983: 376-644.

Chekhov Anton. Povesti i rasskazy. Moskva: Tipogr. t-va I. D. Sytina, 1894.

Chekhov Anton. Sochineniya: V 10 t. Sankt-Peterburg: Izd. A. F. Marksa, 1899-1902.

Chekhov Anton. Polnoe sobranie sochinenij i pisem: V 30 t. Moskva: Nauka, 1974-1983.

Chukovskij Kornej. «O Chekhove». Chukovskij Kornej. Sobranie sochinenij: V 15 t. T. 4. Moskva: Agenstvo FTM, 2012: 195-378.

Cybul'skaya Alla. «"Skripka Rotshil’da” na amerikanskoj scene». Chajka 3 (14) (2004). <https:// www.chayka.org/node/352>.

De Sherbinin Julie. Chekhov and Russian Religious Culture: The Poetics of the Marian Paradigm. Evanston: Northwestern University Press, 1997.

Eremin P. «“Skripka Rotshil’da” A. P. Chekhova - svyaz’ s tradiciyami russkoj klassiki». Voprosy literatury 4 (1991): 93-123.

Etkind Efim. «Ivanov i Rotshil'd». Voprosy literatury 4 (1995): 131-152.

Fasmer Maks. Etimologicheskij slovar' russkogo yazyka: V 4 t. Moskva: Progress, 1987.

Fortunatov Nikolaj. "“Grobovshchik" Pushkina i "Skripka Rotshil'da" Chekhova». Boldinskie chteniya. Gor'kij: Volgo-Vyatskoe knizhnoe izd-vo, 1976: 93-103.

Gejne Genrih. «Lyuteciya». Sobranie sochinenij: V 10 t. T. 8. Moskva: Gosudarstvennoe izdatel'stvo hudozhestvennoj literatury, 1958.

Gofman E. T. A. Rasskazy. T. 1-2. Per. S. M. Bril'yanta i Z. N. Zhuravskoj. Sankt-Peterburg: M. M. Lederle, 1893.

Gofman E. T. A. «Kroshka Cahes, po prozvaniyu Cinnober». Sobranie sochinenij: $V 6 t$. T. 3. Moskva: Hudozhestvennaya literatura, 1996: 171-267.

Gofman E. T. A. «Serapionovy brat'ya. [Sovetnik Krespel']». Sobranie sochinenij: V $6 t$. T. 4, kn. 1. Moskva: Hudozhestvennaya literatura, 1998: 29-54.

Gofman E. T. A. «Serapionovy brat'ya. [Baron fon B.]». Sobranie sochinenij: V 6 t. T. 4, kn. 2. Moskva: Hudozhestvennaya literatura, 1999: 220-230.

Grechko Valerij. «K probleme religioznogo subteksta v proizvedeniyah Chekhova». Reniksa, Tokio, 2 (2010): 148-160.

Jackson Robert Louis. “'If I Forget Thee, O Jerusalem' (An Essay on Chekhov's 'Rothschild's Fiddle"'. Slavica Hierosolymitana 3 (1978): 55-67.

Kasatkina Tat'yana. «Voskreshenie Lazarya: opyt ekzegeticheskogo prochteniya romana F. M. Dostoevskogo "Prestuplenie i nakazanie"». Kasatkina Tat'yana (red.) Dostoevskij: dopolneniya k kommentariyu. Moskva: Nauka, 2005: 203-235.

Kochetov Dmitrij. «Chekhov i Gofman: poetika rubezhnyh epoh». Kataev Dmitrij i dr. (red.) Chekhov i Germaniya. Moskva: MGU, 1996: 37-42.

Kofman Andrej. «Sleduya putyami Bahtina...» Bakhtiniana, São Paulo, 16 (2) (2021): 124-141.

Kotovich Oksana, Kruk Yanka. Zolotye pravila narodnoj kul'tury. Minsk: Adukacyya i vyhavanne, 2010.

Kramer Karl. The Chameleon and the Dream: The Image of Reality in Čexov's Stories. The Hague: Mouton, 1970.

Kubasov Aleksandr. «Semantika narrativnoj struktury rasskaza A. P. Chekhova "Skripka Rotshil'da"». Filologicheskij klass 2 (24) (2010): 67-72.

Lakoff George. "The Invariance Hypothesis: Is Abstract Reason Based on Image-Schemas?" Cognitive Linguistics 1 (1) (1990): 39-74.

Leskov Andrej. «Iz zapisej i pamyati». A. P. Chekhov v vospominaniyah sovremennikov. Moskva: Gosudarstvennoe izdatel'stvo hudozhestvennoj literatury, 1947: 312-322. 
Livak Leonid. The Jewish Persona in the European Imagination: A Case of Russian Literature. Stanford: Stanford University Press, 2010.

Lotman Yurij. «Problema hudozhestvennogo prostranstva v proze Gogolya». Lotman Yurij. Izbrannye stat' $i$ : $V 3 t$. T. 1. Tallinn: Aleksandra, 1992: 413-447.

Papernyj Zinovij. A. P. Chekhov. Ocherk tvorchestva. Moskva: Gosudarstvennoe izdatel'stvo hudozhestvennoj literatury, 1954.

Petrov Yurij. «Lazar' Polyakov: “"moskovskij Rotshil'd”». Anan'ich Boris i dr. (red.) Chastnoe predprinimatel'stvo $v$ dorevolyucionnoj Rossii: etnokonfessional'naya struktura i regional'noe razvitie, XIX - nachalo XX v. Moskva: ROSSPEN, 2010: 411-436.

Petrova Svetlana. «Skripka Rotshil'da»v tvorcheskom dialoge A. P. Chekhova i L. N. Tolstogo. Pushkinskie chteniya. Sankt-Peterburg, 2011: 302-307.

Posse Vladimir. «Vospominaniya o Chekhove». A. P. Chekhov v vospominaniyah sovremennikov. Moskva: Hudozhestvennaya literatura, 1986: 457-464.

Raneva-Ivanova M. «K probleme teorii i metoda izucheniya hristianskogo motiva v proze A. P. Chekhova (o znachenii paskhal'nogo motiva v rasskaze "Kazak")». Evangel'skij tekst v russkoj literature XVIII-XX vekov. Vyp. 2. Petrozavodsk: Izd-vo Petrozavodskogo universiteta, 1998: 484-492.

Rev Mariya. «Vidoizmenenie odnoj literaturnoj tradicii (Pushkin i Chekhov)». Studia Slavica Academiae Scientiarum Hungaricae 36 (1-4) (1990): 325-334.

Rosenshield Gary. "Dostoevskii's 'The Funeral of the Universal Man' and 'An Isolated Case' and Chekhov's 'Rothschild's Fiddle': The Jewish Question”. Russian Review 56 (4) (1997): 487-504.

Senderovich Savelij. Chekhov - s glazu na glaz. Istoriya odnoj oderzhimosti A. P. Chekhova. Sankt-Peterburg: Dmitrij Bulanin, 1994.

Shcheglov Yurij. «Dve variacii na temu smerti i vozrozhdeniya: "Dama s sobachkoj" i "Skripka Rotshil'da" Chekhova». Shcheglov Yurij. Izbrannye trudy. Moskva: RGGU, 2013: 462-482.

Shchepkina-Kupernik Tat'yana. «O Chekhove». A. P. Chekhov v vospominaniyah sovremennikov. Moskva: Hudozhestvennaya literatura, 1986: 227-260.

Suchanek Lucjan. «Prostranstvo zdorov'ya i prostranstvo bolezni (Palata №6, 1892)». Kluge Rolf-Dieter (Hrsg.) Anton P. Čechov. Werk und Wirkung. Teil 1. Wiesbaden: Otto Harrassowitz, 1990: 58-67.

Shmid Vol'f. Proza kak poeziya: Pushkin, Dostoevskij, Chekhov, avangard. Sankt-Peterburg: Inapress, 1998.

Tarasova Natal'ya. «"Voskresenie” i “voskreshenie” v romane F. M. Dostoevskogo "Prestuplenie i nakazanie"». Problemy istoricheskoj poetiki 18 (2) (2020): 190-216.

Tihomirov Boris. «Lazar'! gryadi von». Roman F. M. Dostoevskogo «Prestuplenie i nakazanie» $v$ sovremennom prochtenii: kniga-kommentarij. Sankt-Peterburg: Serebryanyj vek, 2005.

Timasheva Marina. «Raz ty chelovek, to ty est' ispytatel' boli». Peterburgskij teatral 'nyj zhurnal 3 (37) (2004): 14-19.

Tokareva Viktoriya. «Obo vsem ponemnozhku». Tokareva Viktoriya. Mulya, kogo ty privez? Rasskazy. Sankt-Peterburg: Azbuka-Attikus, 2015.

Tolstaya Elena. Poetika razdrazheniya: Chekhov v konce 1880-h-nachale 1890-h godov. Izd. 2-e. Moskva: RGGU, 2002.

Vajskopf Mihail. «Izvlecheniya. Yubilejnoe prinoshenie avtoru "Zapisej i vypisok". Golos Rotshil'da». Novoe literaturnoe obozrenie 73 (2005): 235.

Валериј Гречко

\section{СЕМИОТИКА ПРОСТОРА У ЧЕХОВЉЕВОЈ ПРИПОВЕЦИ „РОТШИЛДОВА ВИОЛИНА“: НЕКОЛИКО ИНТЕРТЕКСТУАЛНИХ ПАРАЛЕЛА}

Резиме

У чланку се анализирају интертекстуалне паралеле у приповеци А. П. Чехова „Ротшилдова виолина“, као и просторне метафоре које су у вези са њима. Посебно се скреће пажња на везу између Чеховљеве приче и јеванђеоских текстова и мотива. Прича о Лаза- 
ревом васкрсењу посматра се као интертекстуални извор наратива о духовној трансформацији јунака Чеховљеве приче, Јакова, и анализира се кроз призму супротности између затвореног и отвореног простора, што је значајно за оба текста. Мотиви новца, камате и изгубљених могућности супротстављају се јеванђеоској параболи о талентима. Као још један интертекстуални извор Чеховљеве приче разматра се новела Е. Т. А. Хофмана „Саветник Креспел“ („Кремонска виолина“). Метафоричко „оживљавање“ виолине, карактеристично за немачке романтичаре, код Хофманна добија амбивалентан израз, у којем је виолина истовремено и извор музике, и „мртви комад дрвета“, који спутава њену слободу. Ову амбиваленцију примећујемо и у Чеховљевој причи, где виолина, с једне стране, постаје метафора душе, а са друге, припада низу објеката који означавају затворене просторе. Чланак показује да се концепт затвореног простора, “футроле”, јавља као унакрсни мотив у Чеховљевом стваралачком опусу, постајући израз егзистенцијалне изолованости човека у свету.

Кључне речи: А. П. Чехов, „Ротшилдова виолина“, интертекстуалност, просторне метафоре, прича о Лазаревом васкрсењу, парабола о талентима, Е. Т. А. Хофман, „Саветник Креспел“". 